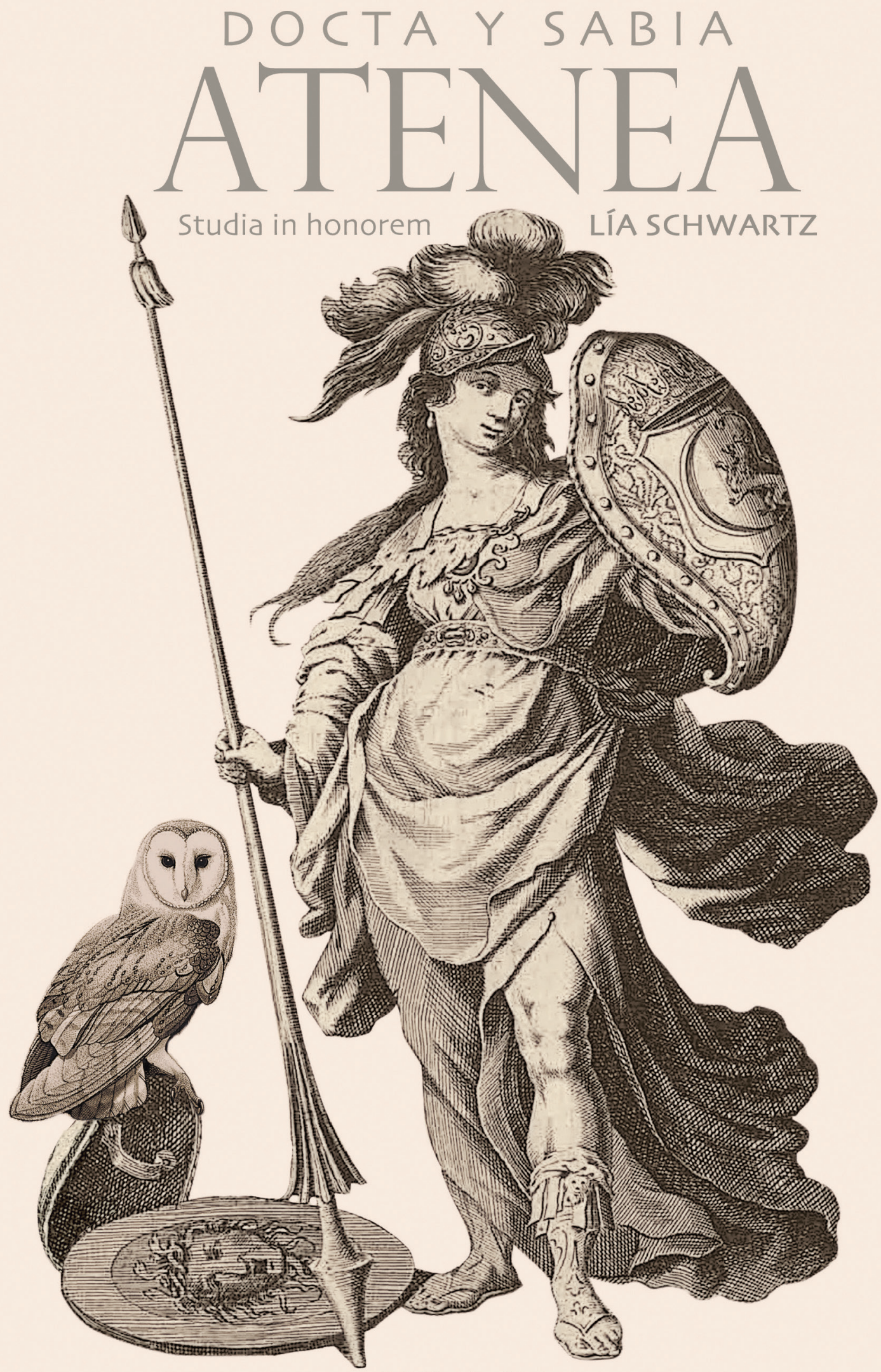

Edición al cuidado de:

SAGRARIO LÓPEZ POZA, NIEVES PENA SUEIRO, MARIANO DE LA CAMPA, ISABEL PÉREZ CUENCA, SUSAN BYRNE Y ALMUDENA VIDORRETA 



\section{DOCTA Y SABIA ATENEA Studia in honorem Lía Schwartz}

Edición al cuidado de:

Sagrario López Poza, Nieves Pena Sueiro, Mariano de la Campa, Isabel Pérez Cuenca, Susan Byrne y Almudena Vidorreta

A Coruña, 2019 

Profesora Lía Schwartz

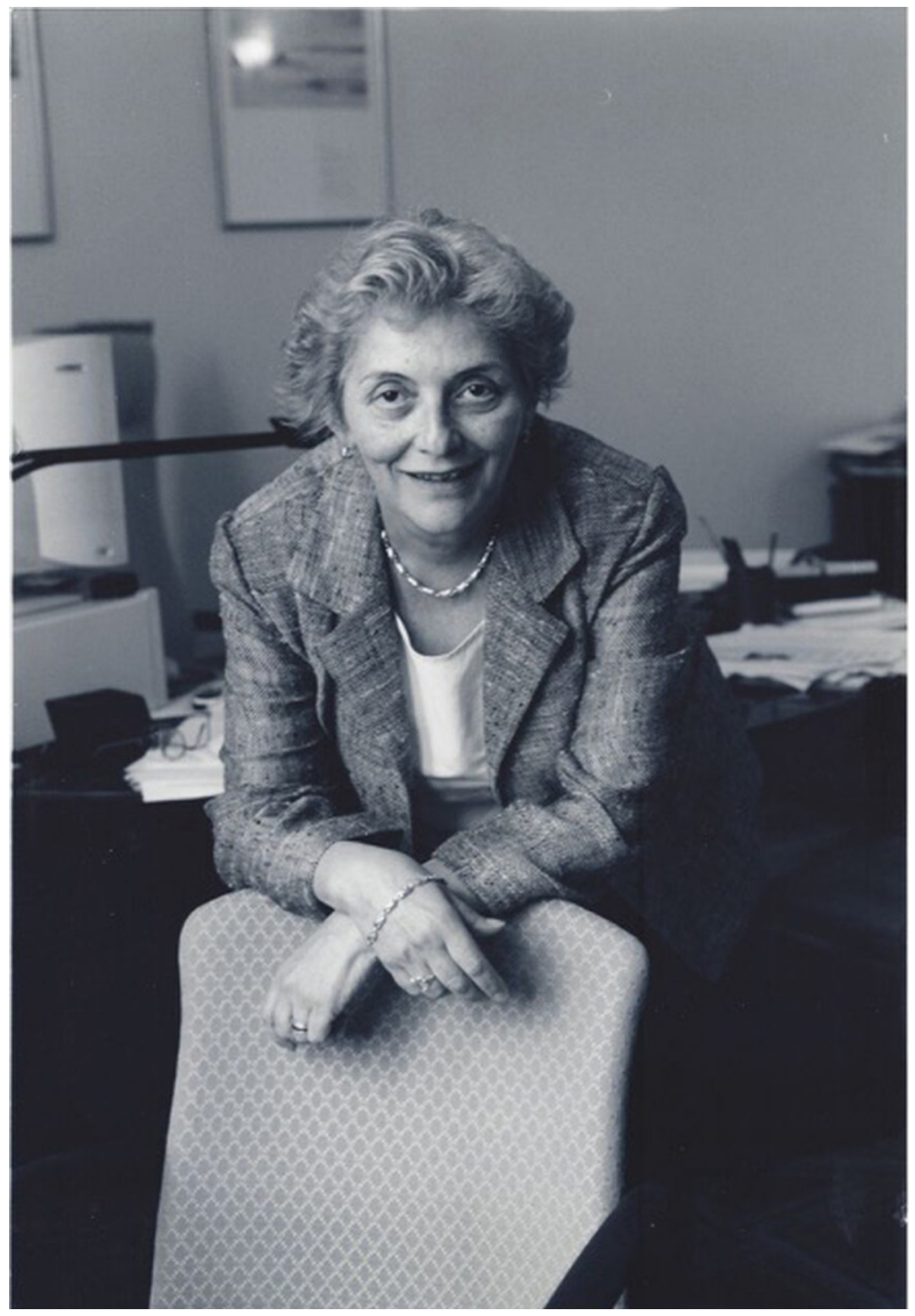


Sagrario López Poza, Nieves Pena Sueiro, Mariano de la Campa, Isabel Pérez Cuenca, Susan Byrne, Almudena Vidorreta (editores)

Docta y sabia Atenea. Studia in honorem Lia Schwartz

N. ${ }^{\circ}$ de páginas: 832

$17 \mathrm{x} 24 \mathrm{~cm}$.

Índice: pp. 7-10

ISBN: 9788497497046

Depósito Legal: C 53-2019

CDU: $821.134 .2(082.2) *$ SCHWARTZ

IBIC: DS | 2ADS | DQ

Editan:

Universidade da Coruña, Servizo de Publicacións

Instituto Universitario "La Corte en Europa" (IULCE), Universidad Autónoma de Madrid

Hispanic Seminary of Medieval Studies (HSMS), New York

Queen Sofía Spanish Institute, New York

Seminario Interdisciplinar para el estudio de la Literatura Áurea Española (SIELAE), Grupo Hispania, Universidade da Coruña

(C) Los autores

(C) De esta edición:

Servizo de Publicacións, Universidade da Coruña

Colección: Homenaxes n. ${ }^{\circ} 14$

Diseño de la cubierta: Paula Lupiáñez (Cirugía Gráfica. Madrid)

Interior: Juan de la Fuente

Impreso en Lugami Artes Gráficas, Betanzos (España)

Printed in Spain 


\section{ÍNDICE}

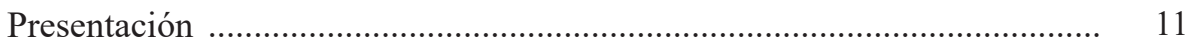

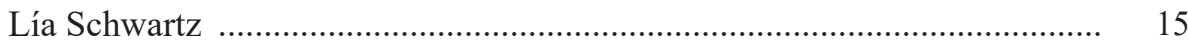

Bibliografía de Lía Schwartz ................................................................. 19

\section{Estudios en homenaje a la profesora Lía Schwartz}

Antonio Azaustre

Notas sobre la filiación en la tradición manuscrita de El alguacil endemoniado

Mercedes Blanco

Para una definición del gongorismo. El caso de Nueva España

69

JAVIER BLASCO

«Salta Pan, Venus baila, Bacho entona»: el campo léxico de la música como vehículo del erotismo en la poesía de los Siglos de Oro

SUSAN BYRNE

La armonía neoplatónica en "A Francisco de Salinas» de fray Luis de León

Mariano de La CAMPa

Poemas de Quevedo en impresos del siglo XVII: Los Romances varios .....

Manuel Ángel Candelas

La poesía española en los manuscritos de la Biblioteca Nazionale di Napoli: noticias y textos

ANTONIO CARREÑo

Lope de Vega: «Rompa ya el silencio el dolor en mí»

Donald CRUickshank

Don Toribio Cuadradillos, «avestruz del amor», and El lindo don Diego (with a note on Quevedo) 
María D'Agostino

Un juego de espejos deformantes. La «representación» del conde de Lemos entre Argensola y Cervantes

TREVOR J. DADSON

«Yo no puedo salir del trabajo de parecer a los portugueses castellano y a los castellanos portugués»: Diego de Silva y Mendoza y la poesía hispanoportuguesa de principios del siglo XVII

Ottavio Di Camillo

Of Roasted Eggs and Other Issues in the Celestina

Aurora EGIDO

Retórica y poética de los afectos en el soneto XIV de Garcilaso 265

Santiago Fernández Mosquera

El vicio de la virtud en Los trabajos de Persiles y Sigismunda 283

Flavia Gherardi \& Pedro Cátedra

El Discorso in difesa della poesia de Gian Ambrogio Biffi en el ámbito de la poética italiana y española

AdRIÁN M. IZqUiERDO

Paráfrasis y experimentación poética en el Anacreón castellano de Quevedo

HILAIRE KALLENDORF

Splitting Hairs or Finding Threads: The Labyrinth as Metaphor for Moral Dilemma in the Comedia

José ENRIQUE LAPLANA

La erudición en el Para todos de Juan Pérez de Montalbán

Begoña LóPEZ Bueno

El Ramillete de las Musas Castellanas (Bibliothèque Mazarine, ms. 4047): un canon literario español en el siglo XVII francés. Primera parte

SAGRARIo LóPez PozA

«Amoris vulnus idem sanat, qui fecit». Notas sobre la fortuna de un topos clásico

ISABEL LOZANO RENIEBLAS

El mal latín del episodio de dos falsos cautivos del Persiles 
Alison Maginn

Rubén Darío's Final Chapter: Archer Milton Huntington and the Hispanic Society

Miguel Martínez

Góngora asiático. Notas sobre poesía filipina inédita del primer Barroco ....

José Martínez MiLlán

Isabel Clara Eugenia, ¿una infanta castellana?

Clayton McCarl

Hacia un modelo para el marcado semántico de los textos marítimos de la época colonial

\section{Juan Montero Delgado}

Un soneto desconocido de Pedro Espinosa a Francisco de Rioja en el ms. Span 56 de la Houghton Library (Universidad de Harvard) 561

Nuria Morgado

Pervivencia del Barroco en la poética de la modernidad: intuiciones y conceptos en el pensamiento literario de Antonio Machado

FRANCISCA MOYA DEL BAÑo

La presencia de Plauto en Quevedo

VALENTINA NIDER

El oro como botín en los poemas de Quevedo sobre Belisario (B-267 e

B-281) y el contexto literario hispano-italiano

ISABEL PÉREZ CUENCA

Francisco de Quevedo y Antonio Sancho Dávila y Toledo Colonna, III marqués de Velada

FERnANDo Plata

El sentido de «barranco» en La Perinola de Quevedo y en otros textos del Siglo de Oro 653

José María Pozuelo Yvancos

Interdiscursividad: cine y literatura en Javier Cercas 671

Augustin Redondo

El tema de la mujer caída de una torre abajo: tradiciones culturales (grecolatinas, bíblicas, folklóricas), creencias religiosas y creaciones cervantinas ... 
MANUEl Rivero RODRÍGUEZ

El conde duque de Olivares, mecenas de la Historia y creador de opinión ... 701

MARIE RoIG Miranda

Los Sueños de Quevedo o cierto tipo de novela 723

Melchora Romanos

Séneca en las Anotaciones de Pedro Díaz de Rivas a los poemas mayores de Góngora

JAVIER SAN JosÉ LeRA

La Política de Dios de Quevedo como comentario bíblico: Política, Biblia y Literatura

LuIs SÁNCHEZ LAÍlLA

Ignacio de Luzán y la musa bucólica

Almudena Vidorreta

Teresa de Jesús, precursora de Gabriela Mistral y Alfonsina Storni

JUAN DiEgo VILA

«con las ansias de la muerte»: El aparato prologal del Persiles como programa estético del estilo tardío cervantino 


\title{
Of Roasted Eggs and Other Issues in the Celestina
}

\author{
Ottavio Di CAmillo \\ Emeritus, The Graduate Center CUNY
}

The hypothesis I am advancing regarding the strong possibility of an Italian translation of the Comedia around the year 1500, may not get much attention, if any, from students of the Celestina who are often not even aware of the 1506 Italian version of the Tragicomedia. ${ }^{1}$ It is an understandable reaction considering the pervasive attitude among past and present critics of either ignoring or underestimating the significance of such a translation. Implicit, however, in overlooking the Rome edition of the work which, according to the colophon, came out in the early days of January 1506 but for all practical purposes can be safely dated to 1505 , there is always the risk of forgetting a crucial fact, namely, the critical awareness that chronologically speaking, the printed Italian translation represents the first extant edition of the work in 21 acts, preceding the first Spanish edition (Zaragoza 1507) by at least two years (Kish, 1973). Equally forgotten is the fact that it was the Italian version, vastly inferior to the Spanish original, on which most of the translations into modern European and ancient languages were made $^{2}$. But, more serious still, is the persisting notion, among scholars who are cognizant of these unusual circumstances, of assuming that the Italian

1 A version of this study was presented at the 48th International Congress of Medieval Studies, Kalamazoo, Michigan, 2013.

2 For the German translation see, Die Celestina-Übersetzungen von Christof Wirsung (1984). For the French translation, see, Celestine: A Critical Edition of the First French Translation (1527)... (1963). 
translation has little to offer in the way of reconstructing the Spanish text's early stages, both in its manuscript and printed tradition. A case in point is that of a group of philologists who in their collective wisdom, but separate expertise, have prepared the latest critical edition of the Celestina (Rojas, 2000: ccxx-ccxxi). Their ecdotic judgments have been so conditioned by such a deeply rooted conviction that they had no hesitation in relegating the Rome edition to a lower place in their stemma, after the Zaragoza and the Valencia editions of the Tragicomedia. In the rush to justify their conclusions, they missed some far-reaching textual consequences regarding some original readings, viewed as mere variants that have only been preserved in the Italian version.

But this has not always been the case among the experts in the field. Miguel Marciales, a little known but most dedicated scholar who spent his entire life studying the extant editions of the Celestina and whose posthumous critical edition is today barely mentioned and even more rarely read, made ample use of the Italian translation in reconstructing the Spanish original text and in amending some of its errors (Celestina. Tragicomedia... 1985, vol. 2). A number of Marciales's textual interventions were also accepted by Peter Russell (2001) in his widely acclaimed edition of the work. Unfortunately, some flaws in Marciales's arguments have often obscured his undeniable and lasting contributions to the study of the Celestina. Nevertheless, some of the extreme intrusions that he made under the guise of restoring the original text, a common practice among the Celestina's critics of the time, cannot entirely be dismissed without considering the still unanswered questions that gave rise to his arbitrary solutions. If nothing else, it is to Marciales's credit his having perceived the underlying complexity of the work's textual composition as it was reworked and modified through several stages of evolution.

Exercising the utmost precaution as required by the peculiar textual condition and aware of the flaws and uncertainties deriving from its belonging to the indirect textual tradition, I can safely state that the text of the Italian Celestina, as I have shown in some of my studies, not only remains the closest to the lost princeps in 21 acts, but it may also conceal, in a palimpsest as it were, traces of an early Comedia. Though it is impossible to determine in what form the work may have circulated, we can at least surmise from the traces it has left that it belonged to a family that has not survived but differed decisively from those of Burgos (1499), Toledo (1500) and Seville (1501), as well as that of the lost edition of 
the Tragicomedia onto which additional material and five more acts were grafted $^{3}$.

As to when a short-lived and continually modified Spanish Comedia makes its irreversible turn into the definitive form of the Tragicomedia, it has long been and still is the object of inconclusive arguments and much speculation. And yet, notwithstanding the absence of any documentary evidence, most Celestina scholars (I among them) quietly assume that the five additional acts, together with a radical revision of the acrostic verses, the introduction of a new prologue and a number of significant interpolations were most likely inserted into the text of a lost branch of the comedia by some unknown humanist, perhaps at the urging of a printer or a sponsor sometime in $1502^{4}$. This date, however, has been reasonably deduced from the rhymed colophon of no less than eight editions of the Tragicomedia ${ }^{5}$. And though a copy of the princeps has not yet been found, it has been established that every one of these editions was actually printed many years later between 1510 and 1520, apparently flooding both the Spanish and the Italian book market. (Of the eight editions with a 1502 date, six have a Seville colophon, one that of Toledo and the eighth bears the name of Salamanca designating not the city but a Spanish printer, Antonio de Salamanca, who was very active in Rome.) Taking these testimonies as a reliable sign of preexisting editions, it is safe to assume that any Italian translation of a Comedia could not have been made before 1502, always

3 The same conclusion, but applied only to the Italian translation of the Tragicomedia, was reached more than half century ago by Emma Scoles (1961: 204-08).

4 Though this predated year has been justified by the fact that in August of 1502 the Catholic Kings emanated an edict, known as Pragmática de Toledo o de los Reyes Católicos, which stated that any book in order to be printed had to acquire a royal license, many printers eluded the new law by changing the actual date of their editions to the year before the ordinance took effect. By the same token that editions of the Celestina bearing the date 1502 were printed much later, one can also assume that the princeps of the Tragicomedia could have been printed any time between 1501 (the date of the Seville edition of the Comedia) and 1505 when the Tragicomedia was translated into Italian.

5 To the six exemplars corresponding to different editions that have survived we can now add two more: one that I discovered in the Naples National Library in 2014 that does not bear a printer's name nor the city of impression, but printed by Juan Varela de Salamanca around 1515, according to the remarkable expertise and erudition of Mercedes Fernández Valladares who has examined the edition, and the other discovered by Charles Faulhaber in the Library of Erfurt University issued from the press of Cromberger also around 1515 or 1517 . 
mindful of the reasonable, but nonetheless, circumstantial evidence on which my assumption rests.

Coinciding with the post quem date of 1502 are chronological events that have been essential for verifying some logical conclusions regarding unique readings reached through a philological analysis of the Italian text of the Celestina. In one instance, as we shall see later, a term used for an Italian theatrical practice, first recorded precisely in this particular year at a theatrical performance in Ferrara, has provided the semantic explanation to an authentic reading that would have remained otherwise incomprehensible. In other cases, historical circumstances dating back to this time have helped to confirm the validity of internal criteria, necessary for selecting juxtaposing variants or for determining whether a lectio singularis can be deemed original or simply a translator's innovation. It is, in fact, in the course of these ecdotic processes, intended to establish a hybrid stemma codicum of both the direct and indirect traditions of the work, that the possible existence of a previous translated Comedia first began to emerge. There were specific readings and variants in the Italian Tragicomedia that could only be explained if they were to belong to a previous translation of an early Comedia.

Unfortunately, these same philological operations have not been able to perceive, however faintly, the possible state or form of such a conjectural Comedia nor the level of its text's evolution. They do point, however, to a family that has not survived in the Spanish textual tradition. At present, my best guess is that such a Comedia would have carried a text that in the evolutionary trajectory that characterizes the early stages of the work can be placed after that of the manuscript of the Palacio with which it shares some unique readings, and prior to that of the Burgos edition (1499). In any case, it would not belong to any of the families represented by the text of the Burgos edition (1499), nor by that of the Toledo (1500) or Seville (1501) editions. Similarly, one can surely exclude any similarity or contiguity with the lost exemplar of the comedia on which all the materials that make up the Tragicomedia as we know it were interpolated.

What is certain is that this early translation must have had some definite bearings on two crucial problems relating to the genesis of the work and its transcultural reception. First, it could very well be that the Comedia was translated for a theatrical representation, a fact that may finally settle the dispute over the work's initial genre, a contention that has long fueled the debate of whether it was first conceived as narrative fiction or dramatic 
representation (novela versus comedia) ${ }^{6}$. Second, the seemingly more practical and ephemeral use of the Italian version, due most likely to its being translated in part by dictation and being cursorily revised, served, nonetheless, as the exemplar on which most modern European languages based their respective early translations. The pioneering works of Emma Scoles and especially of Kathleen Kish who has given us an edition of the Italian and Dutch translation and has never ceased to investigate its textual problems as they relate to the German and Flemish versions, highlight the urgency of further inquiring into such a major contributing factor that made the Celestina a European bestseller. On my part, by playing the archeologist I always wanted to be, I will try to recompose a few pieces of the shattered mosaic of this hypothetical comedia, whose elusive text may forever remain buried under the Italian Tragicocomedia.

Before examining one or two cases pertaining to textual criticism, I would like to comment briefly on a significant extra-textual reference whose historical source I have not yet identified. It has to do with the last week of December of 1501 at the Vatican, and more specifically with the third marriage of the young daughter of Pope Alexander VI, Lucrezia Borgia. In order to celebrate the event with the festivities appropriate to such a special occasion, but also to impress the future in-laws from Ferrara, the pope advanced by decree the beginning of the Carnival's period to the 26 of December. This was the specific time of the liturgical year in which all sorts of entertainments were allowed. In the two weeks that followed, intermixed with banquets, dances, music, and other forms of amusements, including a corrida de toros, there were also several theatrical representations of classical comedies as well as Spanish «ecloghe e pastorali». According to Alvisi (1878: 235), a historian of Cesare Borgia, «la migliore di tutte» was «la Celestina di Rodrigo di Cota che nel $1505 \mathrm{fu}$ tradotta in italiano e dedicata ad una nipote di Giulio II» ${ }^{7}$. What are we to make of this statement? Dismiss it out of hand as a product of a historian's imagination or try to verify its source? Edoardo Alvisi wrote the book from which I am quoting in the 1870 s, and true to his positivistic methodology all information he gives comes from written documents, although not always

6 The question of whether the Celestina is a dramatic play or a dramatic novel in the form of a dialogue has been the object of a debate from the very beginning of literary historical criticism. For a concise account of the contention's issues which has continued to this day, see Álvarez Barrientos, 2001.

7 For a detailed examination of this unusual reference, see Paolini, 2017. 
cited as one would wish. What catches one's attention, however, is the unusual mention of La Celestina by a historian, at a time when this work was not taught in school and thus scarcely known among Spanish literary critics and much less among Italian historians. But even more telling is the fact that he includes the performance among the eclogues rather than referring to the work represented as Comedia, which he seems to ignore, or Tragicocomedia, the Italian extended version in 21 acts, which he certainly knew but must have deemed impractical for representation. Regarding the latter, I have no doubt that he consulted the Rome edition of 1506, of which he speaks, in the Library of the Archiginnasio of Bologna, his city of residence. Be that as it may, while the caption Celestina possibly came from the source he utilized, since it does not appear in the title of the first Italian translation, the name of the presumed author, Cota, does come from the Rome edition, where he is mentioned together with Mena in the letterprologue as possible authors of the first act and thus the shorter version of the work. Without further elaboration, it is conceivable that his source might have also referred to a theatrical representation bearing the name Celestina, since this is the name with which both Italians and Spaniards living in Rome in the early years of the sixteenth century identified the work. In fact, the first recorded occurrence of the name Celestina as a character in a play is found precisely in a dialogue by Baltasar del Río that was published in Rome at the beginning of 1504, but whose actual composition can easily go back to 1503 at the very least (Hernando Sánchez, 2007: 189-237).

Turning now to questions of textual criticism, the marriage celebration of Lucrezia Borgia has again been instrumental in solving the semantic problem of a reading that I could never bring myself to believe was a translator's innovation. It concerns the first act's epigraph which reads: Argumento della prima parte de la tragicocomedia and is totally different from its Spanish counterpart which even in the Tragicomedia retains the old reading: Argumento del primer auto desta comedia. Leaving aside for another occasion this enigmatic demonstrative (de esta comedia) that invites all sorts of speculation, such a notable divergence is a striking departure for a translator like Ordognez whose modus 'traslatandi', if I may coin a phrase, can be characterized for his following word-for-word the base text. As anyone who has dealt with the Italian translation would attest, Ordognez takes the ad verbum mode of translation to the extreme turning it into a kind of verbal transposition from one romance language 
to another even when their respective meanings do not coincide. Since no comedia or tragicomedia of the Spanish tradition calls the first act «primera parte», it follows that Ordognez had a different text in front of him. Could it be, as other textual evidence also seems to indicate, from an earlier Italian translation of the comedia adapted for representation? If this were the case, one can only surmise that Ordognez might have brought up to date a shorter version of the Comedia at a time when a new Tragicomedia in twenty-one acts was rapidly replacing the older play which, despite its literary superiority, was apparently deemed obsolete by the general reader of the time.

Of the festivities that took place in Ferrara to celebrate the arrival of Lucrezia Borgia, we have a detailed account by Niccolò Cagnolo who describes for the French ambassador the daily events organized for the occasion. His meticulous reports not only relate the spectators' astonishment to see and be seen in the first experimental stage built according to Prisciani's Spectacula, but they also detail the performance of five comedies by Plautus that were given in successive nights. It begins with a parade of all the actors taking part in the plays to be enacted; they all wore masks and were ready for the recital («persone larvate e accommodate alla recitazione»); they were followed by one of these persons, named Plautus («nomato Plauto») who recited the arguments of the five comedies. After these presentations, they all moved to another «grandissima sala» where a stage («scena») and a graded semicircular seating arrangement had been constructed for the spectators. That same evening they performed the Epidico, a comedy divided in five parts («era divisa in cinque parti»). Having recited the first part («recitato che ebbero la prima parte»), the actors retired to their «Camere» (the five small houses in the background of the set), and out of these same Camere came ten dancers in costume who performed a dance ${ }^{8}$. The same happened after each of the remaining parts, with brief but elaborate spectacles that varied in themes and performance (Cagnolo, 1867: 48-49).

In view of this specific terminology of theatrical practices used in Ferrara, which was at the time at the vanguard of theatrical experimentation, the first act's epigraph in the Italian version of the work can no longer be dismissed

8 For an analysis of an interrupted transmission of images relating to Terentius's works, from classical times to the Renaissance, see Vescovo, 2016: 313-46; for the Camere, actually similar to today's beach cabins, pp. 327-34. 
as a translator's innovation. The fact that 'parte' instead of 'auto' is used only for the first and eighth act, confirms my belief, as previously stated, that the five acts together with the additional material of the newly called Tragicocomedia were translated and inserted into a previous theatrical version of the Comedia.

Objections may be raised that this reading does not actually affect the text proper of the Celestina, since it is found in the paratext of the work. And yet the first variants that years ago provided me with prima facie evidence of an earlier translation were mostly from El autor a un su amigo, a letter-prologue that reveals the same modus scribendi of the «antiguo autor». The variants of the Italian version may very well be ad verbum translations of the original readings; and though they belong to the indirect tradition an argument can be made for preferring them to the variants of the direct tradition. The alliteration libre liberalidad may very well be a lectio facilior when compared to mera liberalità; the forced redundancy recordable memoria, reacquires its spontaneity in immortale memoria; herrerías de Milán, is a rare case of Freudian slip indicating that the first act was not written by an Italian ${ }^{9}$, whereas ferrarie de Vulcano has literary antecedents; obra discreta seems again a lectio facilior against the more classical adjective in opera diserta ${ }^{10}$. But even before this finding, I had already argued on stylistic and philological grounds that although the letterprologue and the acrostic verses appeared for the first time in the Toledo edition of 1500 , only the acrostic poem was composed for this particular printing and consisted of a «glosa rimada» to the pre-existing letterprologue (Di Camillo, 2001). What appeared at that time to be a daring hypothesis, soon found a partial confirmation. In the prologue to his Glosas a la Trescientas de Mena, published in Seville in 1499, Hernán Núñez, with the characteristic prolixity of a young humanist recently returned from Italy and anxious to impress older men of letters with his learning, elaborates on a few topoi from the letter-prologue which he masterfully weaves into his introduction. Since Núñez's Glosas precede by a year the Toledo edition, where the rhymed colophon and, by extension, the acrostic verses exclude for metrical reasons (hypermetric) any possibility of being composed prior to 1500 , I take it as a further proof that the letter El autor a un su amigo was originally written to justify the first in a series of additions

9 For a study of Freudian slip in textual criticism, see Timpanaro, 1974.

10 I analyzed these terms in Di Camillo, 2007. 
to the Comedia. But until a comedia at such a stage of evolution comes to light to dispel any remaining doubts, the question at this point is to ascertain whether Hernán Núñez had direct knowledge of the Comedia's letter-prologue, in which case such a preliminary text would certainly predate the Burgos edition of 1499, or did he borrow those same topoi from some Latin or Italian humanist letter during his stay in Italy at the Spanish College of Bologna ${ }^{11}$.

Of the several lectiones singulares in the Italian translation that presuppose a text of a Comedia distinct from the others that have survived, I would like to add a few words of clarification to a puzzling syntagm that has attracted a great deal of attention over the years. It is the enigmatic phrase: que encomendador de huevos asados era su marido, against the Italian version that reads: che comandator de buoni arrosti era suo marito (Kish, 1973: 62). The variants in the Spanish textual tradition attest to the difficulty that scribes, correctors and composers in the printing shop had in understanding something that made no sense ${ }^{12}$. The Italian version, on the other hand, though repeating the error (as we shall see, the phrase itself) that was already in the archetype, does reproduce it in its original and semantically correct form, drawing perhaps on an earlier text of the subarchetype, in which the process of diffraction had not yet initiated.

Despite all that has been written to explain this phrase, no critic or editor has cared to remember that throughout the work no allusion is ever made to Celestina having a husband. More important still, they seem to forget that there are many ways to prepare eggs or make omelets, the only thing you cannot do is to roast them. The logical coherence of buoni arrosti (good roasts) of the Italian version, which makes more sense, was most likely in the Spanish original of the conjectured Comedia. In any case, the phrase first appears in the manuscript of the Palacio and, in my estimation, there is reason to believe that it originated precisely in the manuscript tradition, when a careless scribe or one that was unable to make sense of the words, wrote down what he guessed was the correct reading. Moreover

11 Hernán Núñez de Toledo, Las Trescientas del famosissimo poeta Juan de Mena con glosa, Sevilla, Johann Pegnitzer, 1499. Hernán Núñez's Introduction is omitted in the following edition printed by Juan Varela de Salamanca in Granada, 1505. A modern edition is now available prepared by Julian Weiss and Antonio Cortijo Ocaña, <http:// www.ehumanista.ucsb.edu>.

12 For the variants: encomendador, comandador, comedor and the editions in which they occur, see Marciales, 1985: 35, note I.92. 
a $b$ mistaken for a $h$ and an $n$ read upside down as a $u=v$ was a common misreading at that time. As for the reason for the Italian translation of «buoni arrosti» there can be more than one explanation. The translator, facing a word that did not make sense, could have made a reasonable guess or recognizing a cognate he transcribed in Italian. In the latter case he could have mechanically copied it without grasping its meaning or because it made perfect sense to him. Given the immediate context in which the syntagm occurs, namely the apotheosis of Celestina as puta vieja, the sexual innuendo must have made sense to a translator living in Rome, as we learn years later from another Spaniard living in the same city, Francisco Delicado, who in describing the world of prostitutes and their sexual acts in La Lozana Andaluza, also speaks of cocho (an Italianism 'cotto' for cocido) y asado, terms that have nothing to do with the kitchen ${ }^{13}$.

Notwithstanding the disparate articles put out by a virtual cottage industry that has developed over the last several decades and the many efforts in finding a satisfactory explanation of the phrase's meaning, they have only arrived at a myriad of conclusions revolving around the husband's cuckoldry. In all these studies, however, no question has ever been posed regarding the questionable occurrence of the phrase, its problematic nature, and how the proposed meaning is related to the passage's context.

13 In Mamotreto VI, Delicado relates how Diomedes, the Italian merchant, takes the young Aldonza with him to Cadiz, having repeatedly tested or, better still, savored her during their journey: «Juntos a Cáliz (sic), y sabido por Diomedes a que sabía su señora, si era concho o veramente asado, comenzó a imponella según que para luengos tiempos durasen juntos; y viendo su linda carne y lindeza de persona, y notando en ella el agudeza que la patria y parentado le habían prestado, de cada día le crecía el amor, y ansí determinó de no dejalla» (Francisco Delicado, La lozana andaluza, edición y estudio preliminar de Jacques Joset y Folke Gernert, Madrid, 2007, pp. 19-20). The sexual meaning of concho (cocho) and asado has been persuasively explained by Carla Perugini, 2002. Among the sexual references and innuendos lurking in many passages of La lozana andaluza, she explains the terms concho and asado according to the meaning they were given in Italian burlesque literature. She quotes Francesco Berni's In laude d'Aristotele, a name for the male's reproductive organ, that had he written a book on cooking, he would have taught us more than all classical cooks about «arrosto e lesso». These terms' meanings, however, are more explicitly revealed in another passage of the poem where he writes: io ho detto ad Aristotele in secreto, / come il Petrarca: "Tu sola mi piaci». / Il qual Petrarca avea più del discreto, / in quella filosofica rassegna, / a porlo inanzi, come 'l pose drieto (Berni, Rime, 1985, Capitolo LIV). Berni's double entendre is made quite clear in Angelo Firenzuola's Lode della salciccia, where he writes: "A pranzo, a cena o vuo' a lesso o vuo' arrosto; / arrosto é dietro e più da grandi assai, / inanzi é lessa» (see, Commento del Grappa, 1881: 63-76). 
What I have come to realize is that the philological problems concerning a locus criticus as the one in which is found huevos asados cannot be solved by strictly ecdotic procedures alone. Another way would be to focus on the coherence of the logical enunciation as well as in the context in which it is found. In fact, the syntagm happens to occur in one of the most memorable passages of the Comedia, where Pármeno describes Celestina as the universal prototype of «puta vieja» (La Celestina, 2001: 255-56). It is a masterful apotheosis of the old bawd's essential being based on the principle of «nomina sunt consequentia rerum», in which the epithet's words, «puta vieja», are made to reverberate by the unison resounding of natural and human phenomena. Among many passages of the work, this is, in my opinion, the most intellectually charged excerpt where several learned traditions converge: the literary, the juridical, the rhetorical, the philosophical and the linguistic institutions ${ }^{14}$. It is precisely toward the end of a long sequence of different types of sound that we find it interjected, totally out of place and out of order, within the last two phrases: toda cosa que son hace ado quiera que ella está el tal nombre representa, que encomendador su marido de huevos asados, Que quieres mas. Si no que si una piedra topa con otra, luego suena puta vieja.

Since the syntagm within its context is clearly a non sequitur with no logical tie to the preceding and following sentences, the first thing to be considered is how and why it is found at the end of this particular passage. My conjecture, highly probable because of its simplicity, is that it originated as a marginal or interlineal comment made by a reader expressing his personal reaction to the long list of sounds denoting Celestina as «puta vieja». A subsequent scribe who must have used the reader's manuscript to make a copy of the work inserted the comment into the text believing that it was meant to fill a lacuna.

14 The bibliography on interpretatio nominis, especially in dramatic works, is quite extensive. Less attention in literary studies has been paid to a related maxim: nomina sunt consequentia rerum (names are the consequence of things), based on the premise that languages have a natural origin. This belief encapsulates the concept that the nature and character or the very essence of a name or a word is revealed by ordinary natural phenomena. An early use of the aphorism is to be found in Dante's Vita Nova, among many articles on this subject, see the recent study of Benucci (2012). For a very informative treatment of this concept, with valuable bibliographical references, see Guzmán, 1999. For its treatment within the ontological system of reality in medieval and early modern thought see, among others, Montorzi, 2005. 
But whatever the origin, the meaning of the syntagm still needs to be clarified. The general consensus has always been that the phrase is somehow connected to a husband whose wife engages in adulterous acts or, in popular parlance, a husband who wears horns («cuernos») because of his wife's extramarital affair. In our case, such a popular judgment does not really apply since Celestina, being the personification of «puta vieja», makes her living precisely by selling this type of professional services.

Equally disconnected seems to be the term encomendador attributed to the husband. However, a clue as to the origin and meaning of the phrase can be found in the Coplas del Provincial:

59 A ti, fray Cuco Mosquete, de cuernos comendador, ¿qué es tu ganancia mayor, ser cornudo o alcagüete? ${ }^{15}$

Apparently, Fray Cuco Mosquete, probably an appropriate nickname for the type of lucrative activities he engages in, is a comendador de cuernos, implying that he is a husband who deals with goods (cuernos) provided by his wife. The meaning is made quite clear by the verses that follow, in which he is asked which of his two occupations earns him more money, being a cuckold (because of his wife's adultery) or a pimp (for selling her favors)? (¿qué es tu ganancia mayor, ser cornudo o alcagüete?) To which he answers that he makes money in both by providing his wife's services to the Conde de Alba:

$$
\begin{aligned}
& \text { «Así me perdone Dios, } \\
& \text { y no lo digo por salva, } \\
& \text { que de entrambas cosas dos } \\
& \text { he servido al Conde de Alba». }
\end{aligned}
$$

With a similar meaning the term comendador is used in another stanza of the satirical poem: 
49 Ah, fray Alonso de Torres, comendador de los aires, ¿a cómo valen donaires que decís a los señores?: «A fray comer y beber que me dan por los decir, $\mathrm{y}$ tal señor puede ser que a fray algo de vestir».

The cognate of comendador is found in the Italian translation of the phrase: Commandator de boni arrosti. Its meaning in Italian not only coincides with use of the term in the Coplas del Provincial but extends also to the person who has been put in charge of goods that he can sell at auction to the highest bidder ${ }^{16}$.

In conclusion, there is reason to support the hypothesis that the phrase originated in the Coplas del Provincial, an anonymous satire composed in the early 1470's. A reader of the Comedia, still in the early stages of its manuscript tradition, used it as a fitting commentary to Celestina's description as «puta vieja», supposing that, logically, her husband had to be both a cuckold and «alcahuete». The diffraction of the syntagm began when it migrated from the margin of the page into the body of the text.

The unrecognizable form it eventually assumed after a process of misreading, misunderstanding and faulty guessing, hopefully has come to an end. What remains to be done, and I am very confident that the new generation of Hispanists will take on the challenge, is a thorough examination of the chain reaction of compounded errors that ensued and ultimately explain how a simple syntagm, comendador de cuernos morphed into encomendador, comandator de buoni arrosti, and comedor de huevos asados.

16 For the role of the comandadori in Venice, but it was probably true in many other cities, see Welch, 2005, Chapter 7, in particular, pp. 191-94. 


\section{WORKS CITED}

Álvarez Barrientos, Joaquín, «La Celestina, del siglo XVIII a Menéndez Pelayo», in G. Torres Nebrera (coord.), Celestina, recepción y herencia de un mito literario, Cáceres, Universidad de Extremadura, 2001, pp. 73-96.

Alvisi, Edoardo, Cesare Borgia, Duca di Romagna, Imola, 1878; Reprint by Renaissance Books.

Benucci, Alessandro, «Nomina sunt consequentia rerum (Vita Nova, XIII, 4): que reste-t-il de l'adage dantesque dans l'Italie contemporaine?», Revue Silène. Centre de recherches en littérature et poétique comparées de Paris OuestNanterre-La Défense, 14-05-2012, <http://www.revue-silene.com/f/index. php?sp=comm\&comm_id $=108>$.

Berni, Francesco, Rime, ed. Danilo Romei, Milano, Mursia, 1985.

Cagnolo, Nicolò. Lucrezia Borgia in Ferrara sposa a Don Alfonso d'Este, Memorie storiche estratte dalla Cronaca ferrarese di Bernardino Zambotto dov'è inserita la Relazione di Nicolò Cagnolo. Con annotazioni, Ferrara, Domenico Taddei Tipografo editore, 1867.

Celestine: A Critical Edition of the First French Translation (1527) of the Spanish Classic 'La Celestina', ed. Gerard J. Brault, Detroit, Wayne State University Press, 1963.

Commento del Grappa sopra la 'Canzone in lode della salciccia', Bologna, Presso l'Editore Gaetano Romagnoli, 1881.

Delicado, Francisco, La Lozana andaluza, edición y estudio preliminar de Jacques Joset y Folke Gernert, Barcelona, Centro para la Edición de los Clásicos EspañolesGalaxia Gutenberg, 2007.

Di Camillo, Ottavio, «Hacia el origen de la Tragicomedia: huellas de la princeps en la traducción al italiano de Alfonso Ordoñez», in Juan Carlos Conde (ed.), Actas del Simposio Internacional. 1502-2002: Five Hundred Years of Fernando de Rojas' 'Tragicomedia de Calisto y Melibea (18-19 de octubre de 2002, Departamento de Español y Portugués, Indiana University, Bloomington), New York, Hispanic Seminary of Medieval Studies, 2007, pp. 115-45.

Di Camillo, Ottavio, «La peñola, la imprenta y la doladera. Tres formas de cultura humanística en la Carta "El autor a un su amigo" de La Celestina», in Isabel Lozano-Renieblas and Juan Carlos Mercado (eds.), Silva. Studia Philologica in honorem Isaías Lerner, Madrid, Castalia, 2001, pp. 111-26.

Die Celestina-Übersetzungen von Christof Wirsung, Ain hipsche Tragedia (Augsburg 1520), Ainn recht liepliches Buechlin (Augsburg 1534). Mit Holzschnitten von Hans Weidlitz. Herausgegeben und eingeleittet von Kathleen V. Kish und Ursula Ritznenhoff, Mit einem Vorwort von Walter Mettmann, Hildesheim, 1984.

Guzmán, Alejandro, «El communis usus loquendi en el dercho romano», Revista de Estudios Histórico-Jurídicos [Sección Derecho Romano] XXI (Valparaiso, Chile, 1999), pp. 37-64. 
Hernando Sánchez, Carlos José, «Un tratado español sobre la corte de Roma en 1504: Baltasar del Río y la sátira anticortesana», in Carlos José Hernando Sánchez (ed.), Roma y España: Un crisol de la cultura europea en la Edad Moderna. Actas del Congreso Internacional celebrado en la Real Academia de España en Roma del 8 al 12 de mayo de 2007, Madrid, Sociedad Estatal para la Acción Cultural Exterior, 2007, pp. 189-237.

Kish, Kathleen V., An Edition of the First Italian Translation of the Celestina, Chapel Hill, The University of North Carolina Press, 1973.

La Celestina. Comedia o Tragicomedia de Calisto y Melibea, ed. Peter E. Russell, Madrid, Castalia, 2001.

Marciales, Miguel, Introduction to his critical edition of Fernando de Rojas, Celestina. Tragicomedia de Calisto y Melibea, Tomo I: Introducción, Tomo II: Edición crítica, eds. Brian Dutton and Joseph T. Snow, Urbana University of Illinois Press, 1985.

Montorzi, Mario, «Tra retorica ed enciclopedia: l'ontologismo linguistico del giurista medieval», in Atti del XXII Congresso Internazionale dell'International Council of Onomastic Sciences (Pisa, agosto 2005) distributed by Reti Medievali, pp. 1-12.

Núñez de Toledo, Hernán, Las Trescientas del famosissimo poeta Juan de Mena con glosa, Seville, Johann Pegnitzer, 1499.

Paolini, Devid, «Algunas consideraciones sobre la posible representación de Celestina en 1501 en Roma», in Francisco Toro Cevallos (ed.), V Congreso Internacional. Congreso Homenaje a Joseph T. Snow, Centro Virtual Cervantes-Instituto Cervantes, 2017. <https://cvc.cervantes.es/literatura/arcipreste_hita/05/paolini.htm>.

Perugini, Carla, «I sensi della Lozana: analisi polisemica del Mamotreto IV del Retrato de la Lozana Andaluza», in La penna di Venere: Scritture dell'amore nelle culture iberiche, Atti del XX Convegno [Associazione Ispanisti Italiani], eds. Domenico Antonio Cusato and Loretta Frattale, Vol. 1, 2002, pp. 245-54.

Rojas, Fernando de (y «Antiguo Autor»), La Celestina. Tragicomedia de Calisto y Melibea, eds. Francisco J. Lobera... [et al.], Barcelona, 2000.

Rojas, Fernando de, Celestina. Tragicomedia de Calisto y Melibea, Tomo I: Introducción, Tomo II: Edición crítica, eds. Brian Dutton and Joseph T. Snow, Urbana University of Illinois Press, 1985.

Scoles, Emma, «Note sulla prima traduzione italiana della Celestina», Studj Romanzi, XXXIII (1961), pp. 155-217.

Timpanaro, Sebastiano, Il lapsus freudiano. Psicanalisi e critica testuale, Firenze, La Nuova Italia, 1974.

Vescovo, Piermario, «Terentius cum figuris (Preliminari a una ricerca)», Drammaturgia, XIII, 3 (2016), pp. 313-46.

Welch, Evelyn, Shopping in the Renaissance, New Haven, Yale University Press, 2005. 